\title{
Sustainable Development of Natural Gas Vs Renewable \& Alternative Energy at Aburoad
}

SUDHANSU SEKHAR SATAPATHY ( $\nabla$ ssathpathy@gail.co.in )

Jaypee University of Engineering and Technology https://orcid.org/0000-0003-3187-1952

\section{Sandeep Srivastava}

Jaypee University of Engineering and Technology

\section{Original article}

Keywords: Natural Gas, Marketing , Product , Place, Price, Promotion

Posted Date: July 2nd, 2021

DOI: https://doi.org/10.21203/rs.3.rs-636278/v1

License: (c) (i) This work is licensed under a Creative Commons Attribution 4.0 International License. Read Full License 


\section{Abstract}

\section{Background :-}

It has been observed that the development of Natural Gas in the form of Piped Natural Gas for household sector \&Compressed Natural Gas for transport and industrial sector is a part of City Gas Distribution in India is in evolving stage. Before the establishment of Petroleum and Natural Gas Regulatory Board, the sector was not so structured \& directional. Later on, the safety practices of natural gas business were looked into and guidelines were framed. How the strategic marketing of natural gas is done in the form of Piped Natural Gas for household sector \&Compressed Natural Gas which is getting influenced by product supply, pricing mechanism as per demand, place with infrastructure and promotion using innovation \& technologyis also discussed in this paper.

\section{Result :-}

This paper tries to find out the marketing strategies required to make use of natural gas as substitute to all alternative energy like coal, petrol \& diesel and renewable energy like solar \& wind energy available in India and particularly at Aburoad market. The result obtained on the basis of qualitative and quantitative survey indicate that as the natural gas market in India is not so matured and also there is no natural gas market Aburoad. Also the increasing pricing of alternative energy and insufficient availability of renewable energy is paving the path for higher natural gas demand and consumption which is envisaged in future perspective. The results indicate that Infrastructure \&Demand are exerting stronger influence than Supply \&Technology on Natural gas business at Aburoad. It means that the management needs to take steps to build up the Infrastructure \&ensure Demand for strategic marketing of natural gas as compared to alternative and renewable energy.

\section{Conclusion:-}

Considering the climate change and for improving the living standard of the resident in the pollution free environment, it is very much important to proliferate the natural gas market and other renewable energy as compared to alternative energy

\subsection{Introduction}

There is need of the hour to make a long term vision for future energy need looking into climate change. The government has to make broad energy strategy considering the socioeconomically \& geopolitically. Natural Gas is one of the cleanest fuel as compared to coal \& hydrocarbon fuels. Therefore, the share of natural gas can be increased by strategic marketing. Before formulating the strategies for marketing of natural gas business we need to understand the various challenges and opportunities involved in it.

\subsection{The Challnges Of Natural Gas Business}

\subsection{Dependency on import of natural gas for future gas demand}

Though we have to rely on import of natural gas for future growing appetite of natural gas though LNG (Liquefied Natural Gas) transportation by ship and laying new pipeline from other countries, but the spot price 
and long term contract pricing of natural gas has to be taken into consideration in addition to added benefit of clean \& healthy environment due to less air pollution.

\subsection{Less development in Market oriented Pricing}

As the natural gas is completely controlled by PNGRB, the high import price of natural gas is increasing the fertiliser cost and hence the fertiliser industry is given priority to domestically produced gas. At the same time the electricity sector depends more on natural gas which is imported for competing with coal in power generation. Hence a crucial step has to be taken by government to create a broad market oriented administrative pricing mechanism (APM) for natural gas across all consuming sectors.

\subsection{Conflicting interest among ministries}

Due to conflicting interest among ministries dealing with energy supply like petroleum and natural gas, power, coal, renewable energy and atomic energy and ministries dealing with energy demand like road transport, railways, urban development and cultivation, the proper marketing of natural gas is facing a challenge.

\subsection{Requirement of robust policy for future investment}

It is not possible to have long term policy for future investment in natural gas business without proper data analysis. As the natural gas which was earlier considered as scarce is now abundantly available due to discover of shale gas, cold bed methane and liquefied natural gas market.

\subsection{Issue of geopolitics in importing gas through pipeline}

There has been discussion going on importing natural gas through pipeline from countries like Iran but there is geopolitics involved because of Pakistan. Also there is issue that Iran may transport gas to Chaina instead of India due to geopolitics. However, infrastructure in the form City gas distribution for PNG connections are being developed through smart city concept in order to convert to a gas based economy.

\subsection{The Opportunities Of Natural Gas Business 3.1 High population:}

It isforecasted that the population is going to rise in world by 2030 . However it is an opportunity for the developing country that the younger age population shall be more as compared to aging population in other developed counties. This increase in population will ensure more natural gas consumption.

\subsection{Increased GDP due to globalisation :}

As the GDP increases with respect to globalisation, the per capita energy consumption also increases. It is forecasted that by 2030 GDP will increase in addition to increased population which will pose an opportunity for higher natural gas consumption

\subsection{Thrust on Sustainability and Climate Change :}

There is more thrust on the suitability and clean environment in the form of reducing $\mathrm{CO} 2$ emission and other greenhouse gases which are resulting to global warming. Hence it is a opportunity for increase in the natural gas consumption because it as clean and green fuel. 


\subsection{Different Aspect Of Natural Gas Bisiness}

In order to market the natural gas business, it is need to understand following facts so that parameters can be set for formulating strategies.

- Existing gas business in the form of CGD market

- Application of natural gas

- Advantage of Natural gas

- Natural gas Setup

\subsection{Existing gas business in the form of CGD market}

There are various joint ventures and subsidiary companies, which are doing the gas business in the form of city gas distribution (CGD). In addition to above some more companies are also have taken authorisation from PNGRB for CGD business across various cities. There has been 9th round of bidding competition from PNGRB to distribute the authorisation to various companies.

\subsection{Application of natural gas}

In City Gas Distribution system, Natural Gas is used mainly in two forms:

1. Piped Natural Gas (PNG)

2. Compressed Natural Gas (CNG)

\subsubsection{Piped Natural Gas (PNG):}

Piped natural gas (PNG) is used in cooking, water \& space heating in domestic sector and in generating electricity, fertilizers \& petrochemicals etc. in industries and commercial sector respectively. The PNG is pollution-free, safe, economical and user friendly fuel. As PNG connection is directly connected to the delivery point, hence there is no requirement of cylinder booking, waiting delivery and storage space.

\subsubsection{Compressed Natural Gas (CNG):}

After compressing natural gas at a pressure of $200-250 \mathrm{Kg} / \mathrm{Cm} 2$, it becomes CNG. It is a substantially low cost and environment friendly than the conventional liquid auto fuels like petrol \& diesel. The burning of CNG as auto fuel reduces dangerous gas emissions like $\mathrm{CO}, \mathrm{CO} 2$ and other particles from vehicle.

\subsection{Advantage of Natural gas}

The Natural gas is dirty free, safe to use, and most suitable forms of energy in our daily life. The various advantage of natural gas is as given below:-

\subsubsection{Supply of natural gas without any interruption}

There is continuous supply of natural gas through PNG Connection and there is no need to store the gas just like to LPG cylinder. Hence the supply of natural gas is uninterrupted.

\subsubsection{Convenient to use as compared to other alternative fuel}


As compared to other alternative fuel like petrol, diesel \& LPG, the domestic consumer need not to wait for his/her turn to fill the cylinder / fuel tank after booking. PNG also eradicates the cumbersome routine of checking LPG refill cylinder for any doubted leakage, or it being underweight, at the time of delivery at the door step.

\subsubsection{Safe to use handle and use}

As natural gas is lighter than air and in case there is leakage in PNG connection, it disperses in to the air with adequate ventilation whereas LPG being heavier than air will settle at the bottom near the floor surface.

\subsubsection{No hassle in measurement and billing}

As there is no misuse of natural gas in PNG due to no possibility of any pilferage so, the consumer is charge with the quantity it has used accordingly to meter. The user has to pay only after consumption of gas unlike LPG cylinder.

\subsubsection{Prompt Service to customer}

Due to round-the-clock customer support backed by control rooms \& toll free number, any sort of complaint in PNG connection is quickly addressed.

\subsubsection{Low accost and Eco friendly}

The natural is clean and green fuel available at low cost as compared to other alternative fuel

\subsubsection{No wastage of fuel}

As PNG is supplied through pipe, so there is no wastage of fuel as compared to other fuel like petrol, Diesel etc.

\subsubsection{Maintenance free system}

With PNG, the gas stove remain clean and maintenance free.

\subsection{Natural gas Setup}

The natural gas infrastructure is mostly concentrated in one region and action is being taken by government to increase the same in other part of the country in the form of new pipeline. As a particular case if we see the map of India mentioning the natural gas infrastructure, we can understand about the existing and upcoming LNG terminals, existing and planned natural gas transmission pipeline, existing and planned city gas distribution network across India. From the Fig.-1, we can understand already the infrastructure for natural gas is available in India and particularly at Aburoad

\subsection{Research Methodology}

The strategic marketing of the natural gas on the basis of following research model and adoption of methodology. It is done through technical feasibility study considering the qualitative survey \& quantitative survey. 


\section{1 : Qualitative survey}

The qualitative survey is done by considering factors applicable for PNG on the basis of Income, Family size, eating habit, alternative use and food preparation and for CNG on the basis Income, Family size, Availability of Vehicle, Alternative use and Driving habit

\subsubsection{Qualitative survey for PNG ( Piped Natural Gas) connection for Household sector}

- Income : There are mostly Middle income and Low Income population

- Family size : The family size are mostly nuclear type having @4 Nos. person /family.

- Eating Habit : Veg / Non Veg : As the Abu Road is near Tourist place Mount Abu, therefore there is 50:50\% of Veg \& Non Veg category

- Alternate use : Induction Cooker : As the electricity cut is less from RSEB, therefore it is presumed that mostly people of Abu Road are using Induction Cooker in combination with LPG cylinder.

- Food Preparation : Self / Servant based : As the income is low to Medium, mostly people are preparing their food self. Also As the Abu Road is near Tourist place Mount Abu and Ambaji, there are so many hotels in Aburoad where food are prepared by cook/ servants.

\subsubsection{Qualitative survey for CNG(Compressed Natural Gas) connection for Industrial \& Transport sector}

- Income: There are mostly Middle income and Low Income population

- Family size : The family size are mostly nuclear type having @4 Nos. person per family.

- Availability of Vehicle / Industry : Two Wheeler / Four wheeler,Small /Medium /Large : There are mostly four wheelers due to nearest tourist place and nearest highway connecting both Gujarat and Rajasthan boarder.

- Alternate Energy : Petrol/Diesel/Electricity : Consumption of Petrol / Diesel/ Electricity : There is mostly dependent on Petrol / Diesel / Electricity and hence demand is more for consumption of natural gas once made available.

- Driving habit : Self / Servant based : As the income is low to Medium, mostly people are driving self. Also As the Abu Road is near Tourist place Mount Abu and Ambaji, there are so many hotels in Aburoad, hence there are more taxi / buses are there which are run by derivers. : Hence consumption of natural gas shall be more.

\section{2 : Quantitative survey :}

The natural gas consumption all across world has been increased because of it's $\mathbf{4}$ distinct characteristics namely Abundance, Availability, Affordability and Acceptability as it more cleaner than coal or other liquid fuels. Therefore, it is being used for Residential, Industrial and Transportation sector for which strategic marketing must be made by different companies in the city gas distribution market 
The quantitative survey is basically on the basis of primary data collection ,analysis and testing the hypothesis on the basis of research model. In the research model the dependent variable is Strategic marketing through Technical feasibility study and independent variable are Product for Supply, Place with Infrastructure, Price as per Demand \& Promotion using Technology

\subsection{Formulation Of Marketing Strategies For Gas Business}

Abu Road is a Municipality city in district of Sirohi, Rajasthan. The Abu Road city is divided into 31 wards for which elections are held every 5 years. The Abu Road Municipality has population of 55,599 of which 29,454 are males while 26,145 are females as per report released by Census India 2011. The Abu Road has various pumping station ,LPG distribution agencies and Fuel Transporters and future PNG \& CNG connection. In order to formulate a marketing strategy for natural gas business, the four aspect i.e Product, Place, Price and Promotion need to be considered

\subsection{Augmenting natural gas supply as Product}

The natural gas supply as a product has to bemade proper with increase in domestic production by using new technologies and importing natural gas through LNG and regasification of the same in terminals and transporting through pipelines to end consumers.

\subsection{Proliferation of natural gas through building infrastructure at Place}

With the deregulation of natural gas market and need of upcoming city gas projects, Urja Ganga project as a part of national gas grid and creation of future gas trading hub in India and opening of various LNG terminals there has been proliferation of natural gas business in India.

\subsection{Engagement of natural gas with less Price}

With so many LNG projects coming up across world, it is need of hour to attract major gas industries to invest and be part of the growth of India. This will result in ensuring uninterruptable gas supplies and developing transnational pipelines so that India is engaged with international gas market with less Imported price vs Domestic price.

\subsection{Competition using Technology through Promotion}

There has been implementation of policy to separate the marketing and transportation business in gas industries so as ensure common carrier access to infrastructure. This will enhance the competition and provide options to the customer for getting the PNG \& CNG connections.

\subsection{Research Model}

\section{Dependent Variable}

1. Strategic marketing of natural gas business 
Independent Variable

1. Product for Supply

2. Place with Infrastructure

3. Price as per Demand

4. Promotion using Technology

\subsection{Research Hypothesis}

$\mathrm{H} 1$ :The Supply will positively affect the strategic marketing of CGD business

$\mathrm{H} 2$ :The Demand will positively affect the strategic marketing of CGD business

H3 :The Infrastructure will positively affect the strategic marketing of CGD business

$\mathrm{H} 4$ :The Place will positively affect the strategic marketing of CGD business

\subsection{Data Analysis And Result}

\section{Table-1: Reliability Statistics}

Cronbach's Alpha Cronbach's Alpha Based on Standardized Items $\quad \mathrm{N}$ of Items

.941 .943

15

Table-2 :-KMO and Bartlett's Test

Kaiser-Meyer-Olkin Measure of Sampling Adequacy.

.888

Bartlett's Test of Sphericity Approx. Chi-Square

12409.938

df

105

Sig.

.000 


\section{Table-3:- Model Summary}

\begin{tabular}{lllllllllll} 
Model & $\mathrm{R}$ & $\begin{array}{l}\mathrm{R} \\
\text { Square }\end{array}$ & $\begin{array}{l}\text { Adjusted } \\
\mathrm{R} \text { Square }\end{array}$ & $\begin{array}{l}\text { Std. } \\
\text { Error of } \\
\text { the } \\
\text { Estimate }\end{array}$ & \begin{tabular}{l} 
Change Statistics \\
\cline { 5 - 6 }
\end{tabular} & $\begin{array}{l}\text { R Square } \\
\text { Change }\end{array}$ & F Change & df1 & df2 & $\begin{array}{l}\text { Sig. F } \\
\text { Change }\end{array}$ \\
\hline 1 & $.784^{\mathrm{a}}$ & .615 & .613 & .50862 & .615 & 240.895 & 4 & 603 & .000
\end{tabular}

a. Predictors: (Constant), NGT, NGS, NGI, NGD

\section{Table-4: ANOVA}

Model

1
Sum of

Squares

Regression

Residual

Total

249.271

155.991

405.262

df

Mean Square

F

62.318

240.895

$.000^{\mathrm{a}}$

$603 \quad .259$

607

a. Predictors: (Constant), NGT, NGS, NGI, NGD

b. Dependent Variable: TFCB

\section{Table-5:Coefficients}

Model Unstandardized Coefficients

B

B Std.

Error

1

1

(Constant)
NGS
NGD
NGI
NGT

.194

.137

.140

.030

.405

.030

.258

.037

.210

.037

Standardized Coefficients

Beta

$\sqrt{2}$

.129

.440

.226

.184
Sig. Collinearity

Statistics

Tolerance VIF

a. Dependent Variable: TFCB

Table-6 : Rotated Component Matrix

Component

$\begin{array}{lllll}1 & 2 & 3 & 4 & 5\end{array}$

NGS1

.916

NGS2

.939

NGS3

.911

NGD1 


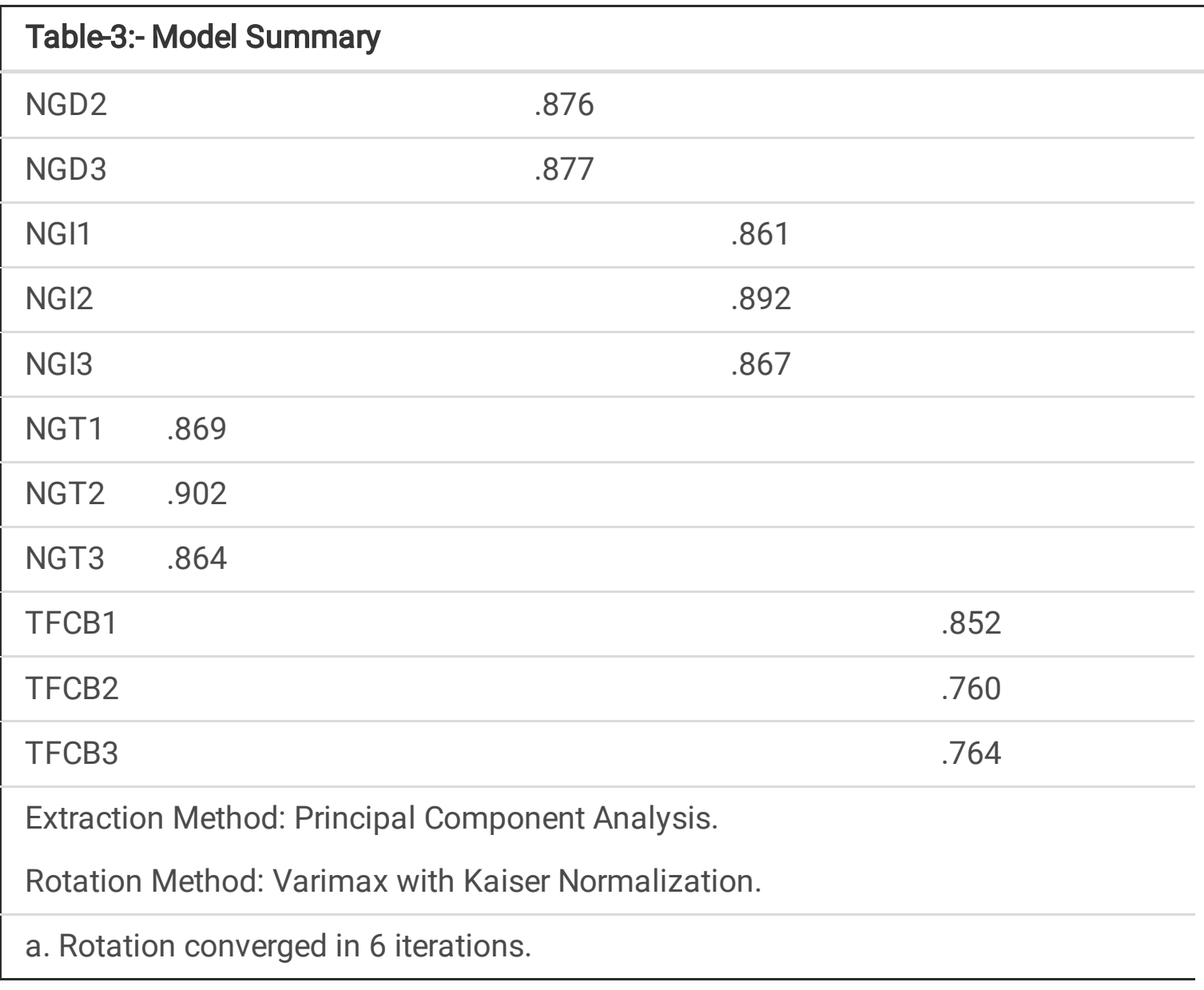

\subsection{Final Outcome}

When testing of hypothesis were conducted using the regression analysis of SPSS 19.0, it is observed that the hypothesis $\mathrm{H1}, \mathrm{H} 2, \mathrm{H} 3, \mathrm{H} 4$ which indicate influence of Supply, Demand, Infrastructure, Technology on Feasibility study of Natural gas business at Aburoad. As expected, Infrastructure $(\beta=.258$, t-value $=7.028)$, Demand ( $\beta$ $=.405$, $\mathrm{t}$-value $=13.284)$ had a strong positive influence on the technical feasibility and Supply $(\beta=.140$, $\mathrm{t}$-value $=4.596)$, Technology $(\beta=.210, t$-value $=5.680)$ had a substantial affirmative effect on the technical feasibility. Hence, hypotheses $\mathrm{H} 1, \mathrm{H} 2, \mathrm{H} 3$ \& $\mathrm{H} 4$ were sustained. Also we establish that the overall predictive fitness of data with the model is in order $\left(R^{2}=61.5 \%, F=\right.$ value $\left.=240.895\right)$.

\subsection{Future Perspective Of Natural Gas Bussineass}

It is observed from the qualitative and quantitative analysis for city gas distribution business at Aburoad that in the PNG and CNG sector the natural gas consumption shall be more considering various factors like Income, Eating habit, Alternative energy used, Family size, Availability of industry and driving habit etc. in addition to availability of following existing \& probable infrastructure to boost the natural gas consumption in the form of :-

1. Existing filling stations which can be converted to future CNG station

2. Existing LPG Agency which can converted to future PNG/CNG agency

3. Existing natural gas pipeline which can be used future PNG/ CNG connection

4. Future CNG Stations 
5. Future PNG Connection :-

11.1 Existing filling stations which can be converted to future CNG station

- HP PETROL PUMP - AMBICA FILLING STATION

- MANPUR PETROL PUMP

- HP PETROL PUMP - HAMARA PUMP SIYAWA

11.2 Existing LPG Agency which can converted to future PNG/CNG agency

- ARBUDA GAS AGENCY

- SIROHI INDANE GAS SERVICE AGENCY

- ASOPALAV HP GAS AGENCY

11.3 Existing natural gas pipeline which can be used future PNG/ CNG connection

- GIGL GAS PIPELINE AND CNG STATION

- IRM ENERGY GAS PIPELINE

- GAIL LPG PIPELINE

11.4 Future CNG Stations

- Sidhivinayak petroleum -HPCL, Bhima village

- Sagar Petrolum -IOCL Bhimana village

- Shri shyam petroleum -IOCL Madar

- COCO station-Akrabhta -Manpur region

11.5 Future PNG Connection :-

- Aburoad city area

- Riico Industrial area

- Talheti area

- Manpur area

From below the map showing the potential consumption of natural gas in Aburoad industries and societies in the form PNG connection and CNG for transportation sector

\subsection{Discussion}

12.1 As per study conducted by Mike P. Jackson in the year 2007 in the paper "The Future of Natural Gas in India: A Study of Major Consuming Sectors" it is observed that gas pricing, supply and infrastructure have been given substantial importance in acknowledging the future of gas market and in addition to this the policies have the largest impact on overall gas demand in India. 
12.2 As per study conducted by Akinyele, Samuel Taiwo in the year 2010 in the paper "Strategic Marketing Management of Oil and Gas Industry: A Review of Literature" the strategic marketing is basically positioning the organisation for enhancing the development of new products/services in the prevailing markets. Similar is the case for strategic marketing of natural gas business at Aburoad where already other alternative energy are available.

12.3 As per study conducted by Subrat Sahu and Varun Singh in the year 2013 in the paper "Natural Gas Business and Market in India" The evolving consumption of Natural Gas through Innovative Technology, Best Practices and Development are prime mover for it's huge demand in the Natural Gas business and market.

12.4 As per Global agenda council on future of oil \& gas in World Economic Forum, 2016 , the oil \& gas industries have to do strategic marketing of natural gas as vis-a-vis low-carbon sources of renewable energy as supplements especially to maintain market share by addressing the technological challenges associated with other alternative and renewable energy to develop efficient combinations of large-scale energy storage and transportation

12..5 As per Anomitro Chaterji, Madhura Joshi,(2014), Centre staging natural gas , International trend and their relevance in India , the natural gas has often been referred to as a "bridge fuel" - a more environment-friendly fossil fuel than other alternative energy fuel like coal, petrol \& diesel that can reduce pollution in the near future . The natural gas shall also facilitate the gradual transition towards renewable sources of energy.

12.6 As per Swami Nathan Kannan (2014) , on the master thesis , "An analysis of natural gas market in India and the perspectives for future development", The India's energy mix comprises of natural gas, other alternative energy like coal \& oil and renewable energy like Hydro, Wind \& Solar . In the next two decade the natural gas market is going to be fastest growing market.

12.7 As per Muhammad Imran Khan,, Policy options for the sustainable development of natural gas as transportation fuel, Energy Policy 110 (2017) 126-136, it is important to create international experience with natural gas as an alternative transportation. A strategic framework for transition challenges to natural gas vehicles (NGVs) is required which examines the policy instruments, incentives, and economic drivers associated with the adoption of NGVs

12.8 In the present study it has investigated the direct effects of Supply, Demand, Infrastructure, Technology on Technical Feasibility study of Natural gas business at Aburoad .The present study has attempted to show some important Natural gas factors for understanding of feasibility study and to take preventive measure for improving the natural gas business

\subsection{Conclusion}

Strategic marketing of natural gas business can be done thorough proper selection of product, place, price\& promotion considering the various natural gas factors like supply, demand, infrastructure and technology.

In case of Aburoad, the perspective use of natural gas as product is more because of it's geographical location as a suitable place which is situated at the boarder of Gujarat and Rajastan . However with the help of strategic marketing with respect to price and promotion with involvement of public-private partnership the technical 
feasibility of natural gas business is possible at Aburoad. Also there are various societies, colonies, Brmhakumari locatlities are there for future PNG connection and future CNG station are upcoming in near future by various agencies like GGL , IRM energy because of their laying gas pipeline and investment in Natural gas business.

\subsection{Contribution Statement}

There have been marketing studies conducted on various natural gas business in previous research papers, however "strategic marketing " to proliferate the consumption of natural gas as transportation fuel has not been made. In the present study, a research model has been framed looking into various marketing factors of the natural gas business and collecting \& analysing the data on these factors. This study has done the market analysis before establishing a natural gas as transportation fuel on the basis consumer behaviour.

\subsection{Declarations}

15.1 Ethics approval and consent to participate: Not applicable

15.2 Consent for publication : Not applicable

15.3 Availability of supporting data

All data generated or analysed during this study are included in this published article [and its supplementary information files]

15.4 Competing interests: We have no competing interests

15.5 Funding: Not applicable

15.6 Authors' contributions 


\begin{tabular}{|l|cc|}
\hline Contribution & [Author 1] & [Author 2] \\
\hline 1. Definition of research problem & $\sqrt{ }$ & $\sqrt{ }$ \\
\hline 2. Development of hypotheses or research questions (empirical studies) & $\sqrt{ }$ & $\sqrt{ }$ \\
\hline $\begin{array}{l}\text { 3. Development of theoretical propositions } \\
\text { (theoretical work) }\end{array}$ & $\sqrt{ }$ & $\sqrt{ }$ \\
\hline 4. Theoretical foundation / Literature review & $\sqrt{ }$ & \\
\hline 5. Definition of methodological procedures & & $\sqrt{ }$ \\
\hline 6. Data collection & $\sqrt{ }$ & \\
\hline 7. Statistical analysis & $\sqrt{ }$ & $\sqrt{ }$ \\
\hline 8. Analysis and interpretation of data & $\sqrt{ }$ & $\sqrt{ }$ \\
\hline 9. Critical revision of the manuscript & $\sqrt{ }$ & $\sqrt{ }$ \\
\hline 10. Manuscript writing & $\sqrt{ }$ & $\sqrt{ }$ \\
\hline 11. Other (please specify) & & \\
\hline
\end{tabular}

15.7 Acknowledgements : Not applicable

\subsection{References}

1. Akinyele S, Taiwo, "Strategic Marketing Management of Oil and Gas Industry: A Review of Literature" Journal of Business Management and Economics Vol. 1(1). pp. 001-009, October, 2010

2. Abdul Atheem H (1995) Economical Feasibility Studies and Project Evaluation. Al-Nahda Al-Misriah Bookshop, Egypt

3. Hamid A (2000) Abdul Muttaleb. Feasibility Study for Investment Decision

4. Akinyele ST (2010) Strategic marketing practices on the performance of firms in Nigerian oil and gas industry. Int J Res Commer Manage 1(4):6-33

5. Ansoff H (1988) Strategic Change and the Strategic MarketingProcess. Blackwell, Oxford

6. Anomitro, Chaterji, Madhura Joshi,(2014), Center staging natural gas, International trend and their relevance in India

7. Bailey JE, Pearson SW (1983) Development of a Tool for Measuring and Analyzing Computer User Satisfaction. Manage Sci 29:No.5:30-545

8. Beatty SE, Kahle LR, Homer P, "The Involvement-Commitment Model: Theory and Implications,Journal of Business Research, Vol. 16, No. 2:149-167, March 1988

9. Berry LL (1999) Discovering the Soul of Service. The Free Press, New York

10. Bagozzi RP, Yi Y (1988) On the evaluation of structural equation models. J Acad Mark Sci 16:74-94 
11. Barnes JG (1994) Close to the customer: But is it really a relationship? Journal of Marketing Management $10: 561-570$

12. Berry BW (1997) 'Strategic Marketing Work Book for NonprofitOrganizations',Chicago

13. Barney I (1991) Strategic factors markets: Expectations, luck and business strategy. Manage Sci 32(10):123-1241

14. Chaudhuri A, Holbrook MB, "The Chain of Effects from Brand Trust and Brand Affect to Brand Performance: The Role of Brand Loyalty," Journal of Marketing, Vol. 65, No. 2:81-93, April 2001

15. Craig Robinson Alex Scott, Strategic planning for oil \& gas industry, PI-A1 1/2016 (1052)

16. Crosby LA, Taylor JR, "Psychological Commitment and Its Effects on Post-Decision Evaluation and Preference Stability among Voters," Journal of Consumer Research, Vol. 9, No. 4:413-431, March 1983

17. Crosby LA, Evans KR, Cowles D (1990) Relationship Quality in Service Selling: An Interpersonal Influence Perspective. J Mark 54:No. 7:68-81

18. Chen T (2004) Critical success factors for various strategies in the oil and gas industry. The Int J Service Mark 16:(20)

19. Creveling JP (2005) Making a case for business and marketing planning. Rough Notes 137(3):26-32

20. Centerr

21. DeLone WH, McLean ER, “Information Systems Success: The Quest for the Dependent Variable,"Information Systems Research, Vol. 3, No. 1:60-95, 1992

22. DeLone WH, McLean ER, "The DeLone and McLean Model of Information Systems Success: A Ten Year Update," Journal of Management Information Systems, Vol. 19, No. 4:9-30, Spring 2003

23. Dick AS, Basu K, “Customer Loyalty: Toward an Integrated Conceptual Framework," Journal of the Academy of Marketing Science, Vol. 22, No. 2:99-113, Spring 1994

24. Dodds WB, Monroe KB, Grewal D, “Effects of Price, Brand, and Store Information on Buyers' Product Evaluations," Journal of Marketing Research, Vol. 28, No. 3:307-319, August 1991

25. Gup BE, Whitehead DD (2000) Strategic marketing in banks: Does it pay? Long Range Planning. J. Strateg. Mark. Manage. 17(1)

26. Henry H (1999) The evolution of strategic marketing in major corporations, Proceedings, American Institute of Decision Sciences

27. Hunsaker PL (2001) Effects of formal strategic marketing on financial performance in small firms: A metaanalysis. Entrepreneurship Theory and Practice, Chicago II, Dryden Press

28. Hosmer LT (1995) Trust: the Connecting Link Between Organizational Theory and Philosophical Ethics. Acad Manag Rev 20:No. 2:379-403

29. Howard J, Sheth J, The Theory of Buyer Behavior, New York: John Eiley \& Sons, 1969.Ives B, Olson MH, Baroudi JJ, "The Measurement of User Information Satisfaction," Communications of the ACM, Vol. 26, No. 10:785-793, 1983

30. Hamami Y (2003) The Economic Feasibility Study of the Tourism Projects: Practical Case Study; unpublished MA thesis. Aleppo: University of Aleppo

31. Hair JF Jr, Anderson RE, Tatham RL, Black WC (1995) Multivariate Data Analysis with Readings. Fourth edition, Prentice Hall, 745pp 
32. Hart P, Saunders C (1997) Power and Trust: Critical Factors in the Adoption and Use of Electronic Data Interchange. Organ Sci 8(1):23-41

33. Hoyle RH, Panter AT (1995) “Writing about structural equation models”. In: Hoyle RH (ed) Structural Equation Modeling: Concepts, Issues and Applications. SAGE Publications, pp 158-176

34. Hu L-T, Bentler PM (1995) “Evaluating Model Fit”. In: Hoyle RH (ed) Structural EquationModeling: Concepts, Issues and Applications. SAGE Publications, pp 76-99

35. Jacoby J, Chestnut R (1978) Brand Loyalty Measurement and Management. John Wiley \& Sons, New York

36. Johnson J, Lee R, Saini A, Grohmann B (2003) Strategic marketing management practice: Conceptual advances and an integrative model. J Acad Mark Sci 31(1):74-89

37. Kelley SW, Davis MA, "Antecedents to Customer Expectations for Service Recovery," Journal of the Academy of Marketing Science, Vol. 22, No. 1:52-61, Winter 1994

38. Kiesler CA, Sakumura J (1966) A Test of a Model for Commitment. J Pers Soc Psychol 3:458-467

39. Kim D, Benbasat I (2003) Trust-Related Arguments in Internet Stores: A Framework for Evaluation. Journal of Electronic Commerce Research 4:No. 2:49-64

40. Kotler P, Singh R, “Marketing Warfare in the 1980's,” Journal of Business Strategy, Vol. 1, No. 3:30-41, Winter 1981

41. Kumar N, Scheer LK, Steenkamp J-BEM, “The Effects of Supplier Fairness on Vulnerable Resellers,\&\#8221

42. Kudler R (1996) The effects of strategic marketing on common stock returns' Acad. Manage J 23(1):5-20

43. Lewis JD, Weigert AJ, "Trust as a Social Reality," Social Forces, Vol. 63, No. 4:967-985, 1985. Lichtenstein DR, Netemeyer RG, Burton S, “Distinguishing Coupon Proneness from Value Consciousness: An Acquisition-Transaction Utility Theory Perspective," Journal of Marketing, Vol. 54, No. 3:54-67, July 1990

44. Mayer RC, Davis JH (1999) The Effect of the Performance Appraisal System on Trust in Management: A Field Quasi-Experiment. J Appl Psychol 84:No. 1:123-136

45. Muhammad Imran Khan (2017) Policy options for the sustainable development of natural gas as transportation fuel. Energy Policy 110:126-136

46. Mayer RC, Davis JH, Schoorman FD (1995) An Integration Model of Organizational Trust. Acad Manag Rev 20:No. 3:709-734

47. McKnight DH, Cummings LL, Chervany NL (1998) Initial Trust Formation in New Organizational Relationships. Acad Manag Rev 23:No. 3:472-490

48. McKnight DH, Choudhury V, Kacmar C (2002) Developing and Validating Trust Measures for E-Commerce: An Integrative Typology. Information Systems Research 13:No. 3:334-359

49. Molla A, Licker PS (2001) E-Commerce Systems Success: An Attempt to Extend and Respecify the Delone and MaClean Model of IS Success. Journal of Electronic Commerce Research 2:No. 4:131-141

50. Moorman C, Zaltman G, Deshpande R, "Relationships between Providers and Users of Market Research: The Dynamics of Trust within and between Organizations," Journal of Marketing Research, Vol. 29, No. 3:314-328, August 1992

51. Morgan RM, Hunt SD, "The Commitment-Trust Theory of Relationship Marketing," Journal of Marketing, Vol. 58, No. 3:20-38, July 1994 
52. Marsh HW, Hocevar D (1985) Application of confirmatory factor analysis of the study of models and their invariance across groups. Psychology Bulletin 97:562

53. McDonald M (2004) Strategic marketing planning: A state of the art review. Marketing Intelligence Planning $10(4): 4-22$

54. McDonald M (1989) Strategic marketing and firm performance. J Mark 2(4):23-40

55. Mike P, Jackson (2007),“The Future of Natural Gas in India: A Study of Major Consuming Sectors” Program on Energy and Sustainable Development, Working Paper \#65

56. Nunnally JC (1978) Psychometric Theory, 2nd edn. McGraw-Hill, NY

57. Oliva TA, Oliver RL, MacMillan IC, "A Catastrophe Model for Developing Service Satisfaction Strategies," Journal of Marketing, Vol. 56, No. 3:83-95, July 1992

58. Oliver RL (1980) A Cognitive Model of the Antecedents and Consequences of Satisfaction Decisions. Journal ofMarketing Research 17:No. 4:460-469

59. Oliver RL (1999) Whence Consumer Loyalty. J Mark 63:Special Issue:33-44

60. Oluyemi SA (1996) Deregulation and the performance of oil and gas industry in Nigeria: An overview. NDIC Quarterly 59(1):49-67

61. Osuagwu L (2001) Adoption of marketing strategies in Nigerian institutions. Acad Mark Studies J 5(1):116

62. Osuagwu L (2004) Relationship marketing strategies in Nigerian companies, The Mark. Manage J $14(2): 114-128$

63. Palvia PC (1996) A Model and Instrument for Measuring Small Business User Satisfaction with Information Technology. Inf Manag 31:No. 3:151-163

64. Parasuraman A, Grewal D (2000) The Impact of Technology on the Quality-Value-Loyalty Chain: A Research Agenda. J Acad Mark Sci 28:No. 1:168-174

65. Pollard C (2003) E-Service Adoption and Use in Small Farms in Australia: Lessons Learned from a Government-Sponsored Programme. Journal of Global Information Technology Management 6:No. 2:4563

66. Reichheld FF, “Learning from Customer Defections,” Harvard Business Review, Vol. 74,No. 2:56-67,MarchApril 1996

67. Robertson TS, “Low-Commitment Consumer behavior,” Journal of Advertising Research, Vol. 16:19-24, April 1976

68. Rousseau DM, Sitkin SB, Burt RS, and C.Camerer, "Not so Different After All: A Cross-Discipline View of Trust" Academy of Management Review, Vol. 23, No. 3:393-404, July 1998

69. Seddeon PB, "A Respecification and extension of the Delone and McLean Model of IS Success," Information Systems Research, Vol. 8, No. 3:240-253, September 1997

70. Shapiro SP (1987) The Social Control of Impersonal Trust. Am J Sociol 93:No. 3:623-658

71. Sheppard BH, Hartwick J, Warshaw PR, "The Theory of Reasoned Action: A

72. Meta Analysis of Past Research with Recommendations for Modifications in Future Research," (1998) J Consum Res 15:No. 3:325 343 
73. Sahu S, Singh V, Natural Gas Business and Market in India" International Journal of Chemical Engineering and Applications, Vol. 4, No. 1, February 2013

74. Scnars SP (1991) Marketing strategy. The Free Press, New York

75. Swami Nathan Kannan (2014), on the master thesis, "An analysis of natural gas market in India and the perspectives for future development

76. Urban GL, Hauser JR (1993) Design and marketing of new products. 2nd edition. Prentice-Hall Inc., Englewood Cliffs, N.J

77. Venkatesh V, Davis FD (2000) A Theoretical Extension of the Technology Acceptance Model: Four Longitudinal Field Studies. Manage Sci 46:No. 2:186-204

78. Voss GB, Parasuraman A, Grewal D, "The Roles of Price, Performance, and Expectations in Determining Satisfaction in Service Exchanges," Journal of Marketing, Vol. 62, No. 4:46-61, October 1998

79. Wang Y-S, Tang T-I, Tang J-TE, "An Instrument for Measuring Customer Satisfaction Toward Web Sites That Market Digital Products and Services," Journal of Electronic Commerce Research, Vol. 2, No

80. Woodward R (2004) Technological expansion: The interaction between diversification strategy and organizational capacity. J Manage Studies 33(3):701-712

81. Wold Economic Forum (2016) Global agenda council. on future of oil \& gas

\section{Figures}

\section{Natural Gas Infrastructure in India}

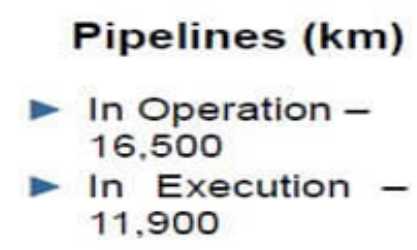

\section{LNG (MMTPA)}

Operating- 26.7

- Upcoming -33.8

\section{(B)) | KATYA}

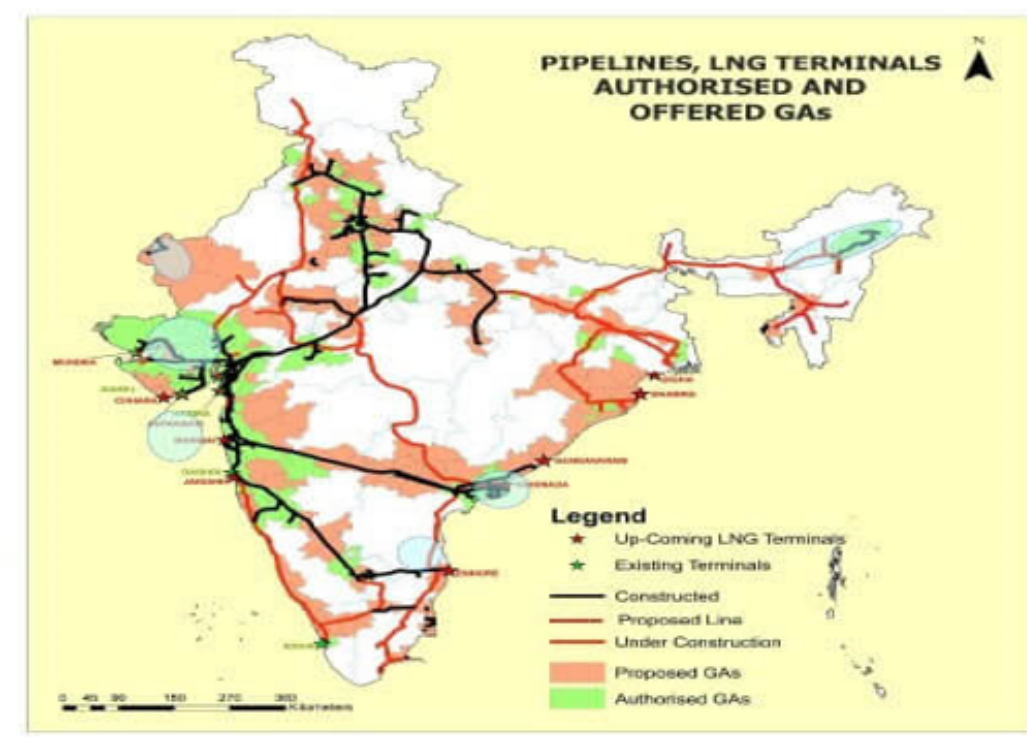

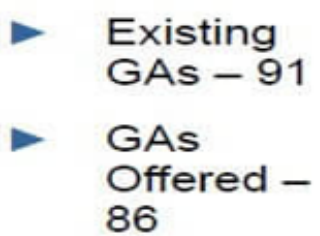

86

\section{Figure 1}

Source: www.citykatta.com 


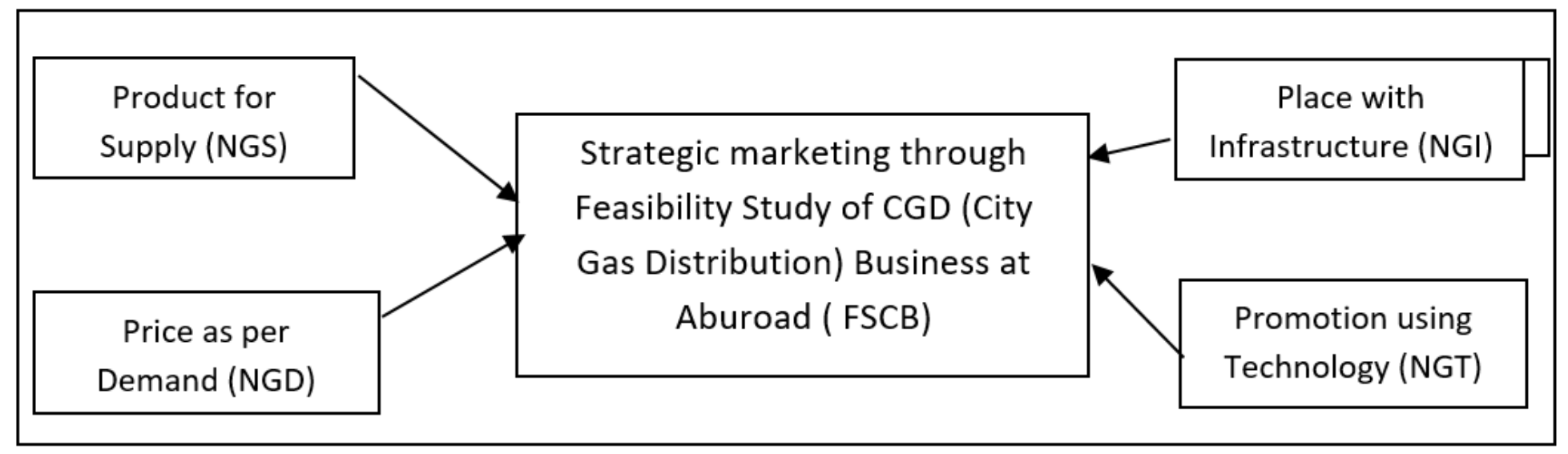

Figure 2

Depiction of Interrelationship amongst various Natural gas factors for Technical feasibility of Natural gas business at Aburoad

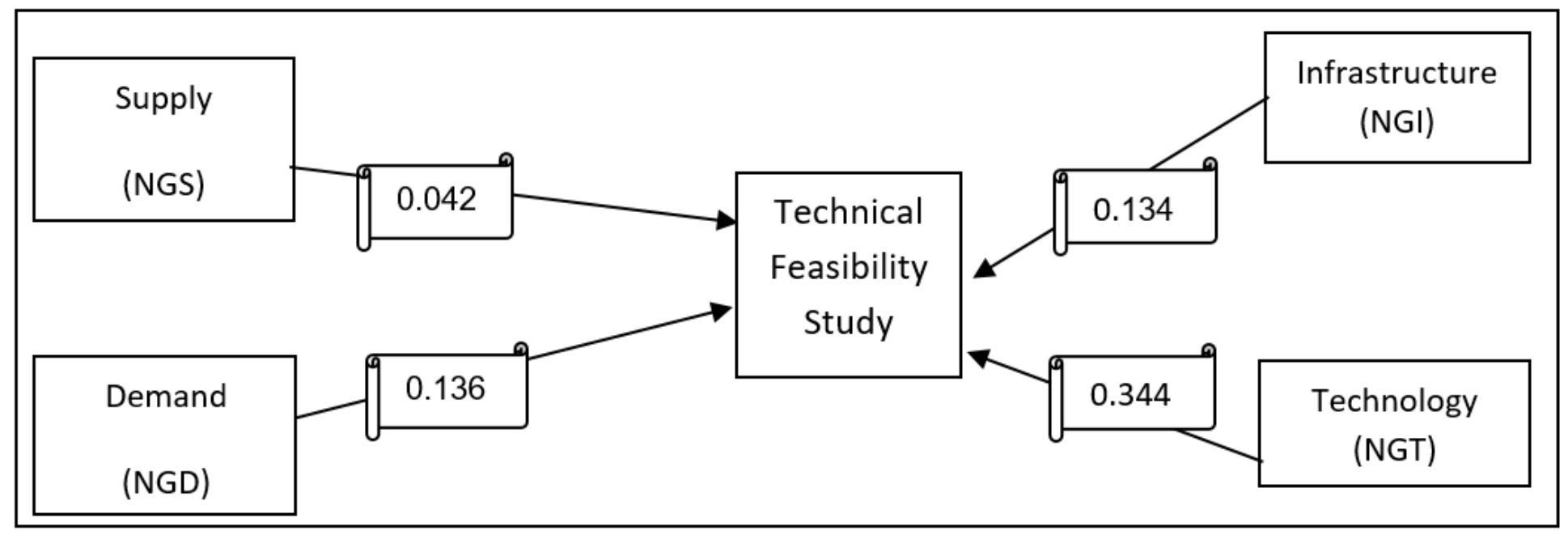

Figure 3

Hypothesis testing for Feasibility study of CGD business at Aburoad

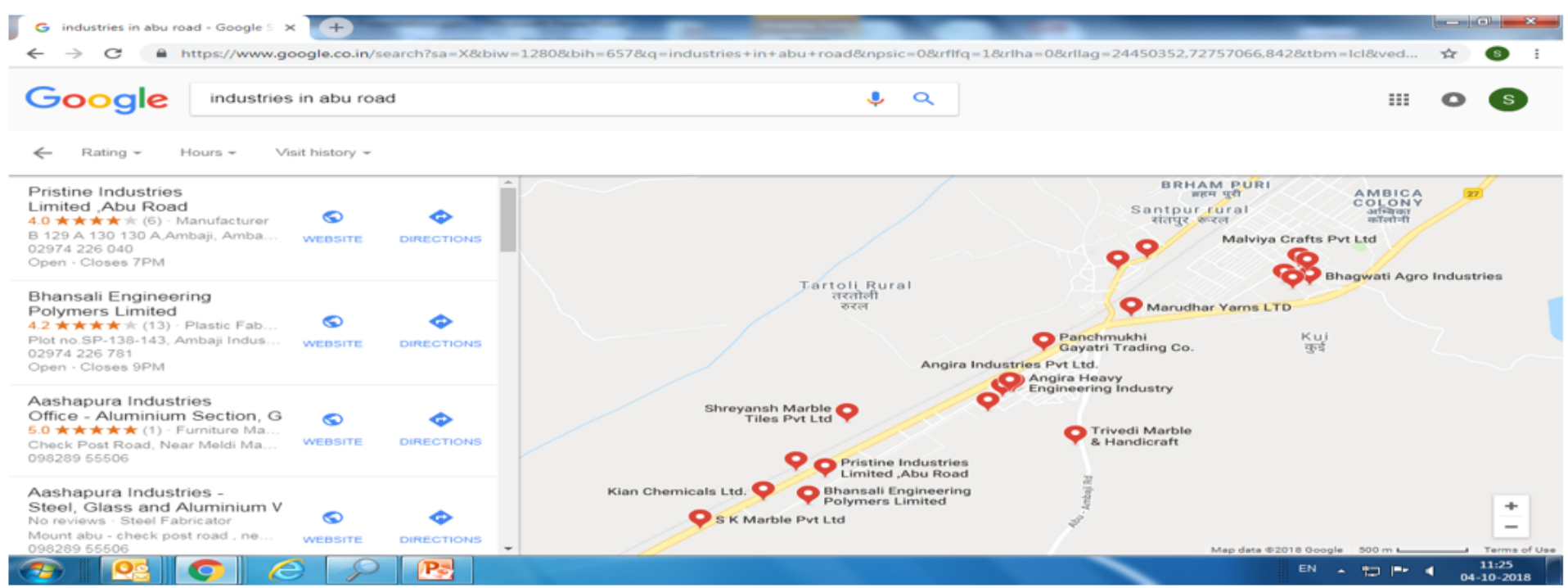


Figure 4

Source: www.google.com for industries in Aburoad 